\title{
KARAKTERISASI KELISTRIKAN AIR PAYAU DAN AIR SUNGAI SEBAGAI BAHAN ELEKTROLIT
}

\author{
SW Suciyati ${ }^{1 \text { a) }}$, Warsito, Amir S, Arif S, Giri AM, Gurum AP \\ 1) Jurusan Fisika, FMIPA, Universitas Lampung \\ Email: ${ }^{a)}$ sri.wahyu@fmipa.unila.ac.id
}

\begin{abstract}
Abstrak
Air payau dan air sungai memiliki potensi sebagai sumber energi alternatif terbaharui. Studi kelistrikan mereka berhasil dilakukan menggunakan prinsip elektrokimia sel volta, yaitu dengan membuat pasangan elektroda disusun secara seri dalam 20 kotak persegi panjang. Elektroda yang dipakai adalah tembaga $(\mathrm{Cu})$, dan seng $(\mathrm{Zn})$, sedangkan sebagai elektrolit adalah larutan air payau dan air sungai. Karakteristik bahan elektrolit diketahui melalui pengukuran tegangan dan arus yang mengalir pada LED (1,2 watt) yang diletakkan pada rangkaian sel elektroda. Pengambilan data pengukuran dilakukan selama 3 hari dengan selang 2 jam. Hasil pengukuran dan analisis untuk kombinasi elektroda $\mathrm{Cu}-\mathrm{Zn}$, menunjukkan air payau memiliki daya kelistrikan lebih besar daripada air sungai, dengan rasio 12,008:5,84 (hari pertama) dan 1,752:0,572 (hari ketiga). Nilai ini juga menunjukkan bahwa air payau sebagai larutan elektrolit mampu menghasilkan energi untuk menghidupkan LED selama 72 jam dengan nilai rata-rata intensitas LED yaitu 322,8 lux.
\end{abstract}

Kata-kata kunci: elektrolit, air payau, sel elektroda, intensitas LED

\begin{abstract}
Brackish water and river water have the potential as an alternative renewable energy source. Their electrical studies have been successfully conducted using the electrochemical principle of voltaic cells, by making electrode pairs arranged in series in 20 rectangular squares. Electrodes used are copper $(\mathrm{Cu})$, and zinc ( $\mathrm{Zn})$, while as an electrolyte is some brackish water and river water. The characteristic of the electrolyte material is known by measuring the voltage and current flowing on the LED ( 1.2 watt) placed on the electrode cell circuit. Taking measurement data is done for three days with 2 hour interval. The results of measurement and analysis for $\mathrm{Cu}-\mathrm{Zn}$ electrode combinations have shown that brackish water has greater electrical power than river water, with a ratio of 12.008: 5.84 (day one) and 1.752: 0.572 (third day). This value also shows that brackish water as electrolyte solution has been able to produce energy to turn on the LED for 72 hours with an average value of LED intensity of 322.8 lux.
\end{abstract}

Keywords: electrolyte, brackish water, electrode cell, LED intensity

\section{PENDAHULUAN}

Pertumbuhan ekonomi dunia membutuhkan pasokan energi yang besar sebagai penggerak utamanya. Pada tahun 2014, kebutuhan konsumsi energi dunia naik menjadi sekitar 13 miliar ton minyak meningkat 22\% dibandingkan dengan pada tahun 2004 dan 54\% pada tahun 1994. Permintaan yang meningkat pesat mempercepat eksploitasi sumber daya energi dari alam dan akhirnya membawa tantangan berat berupa kelangkaan sumber energi dan perubahan iklim. Menurut BP (British Petroleum) pada akhir 2014 mengatakan bahwa cadangan minyak, gas alam, dan batubara 
diperkirakan akan habis 53, 54 dan 110 tahun kedepan. Hal ini menyebabkan konservasi sumberdaya energi saat ini menjadi perhatian penting dunia [1].

Kebutuhan energi listrik di Indonesia terus meningkat seiring pertambahan jumlah penduduk dan pertumbuhan ekonomi. Berdasarkan data ketenagalistrikan nasional tahun 2015, total kapasitas pembangkit yang terpasang adalah sebesar $53.585 \mathrm{MW}$ dengan rincian $70 \%$ PLN, 5\% private power utility (PPU) yang merupakan pembangkit terintegrasi, 20\% independent power producer (IPP) yang merupakan listrik swasta, dan 5\% pembangkit ijin operasi non BBM. Permintaan listrik diperkirakan meningkat dengan laju pertumbuhan $8,8 \%$ per tahun. Persentase pemakaian listrik pergolongan yaitu, rumah tangga $43 \%$, industri $33 \%$, bisnis $18 \%$ dan publik $6 \%$ [2].

Kebutuhan energi listrik yang cukup besar berbanding terbalik dengan ketersediaan sumber energi listrik, sehingga perlu adanya pemanfaatan sumberdaya lain sebagai sumber energi alternatif. Pemanfaatan air sebagai sumber alternatif energi listrik menjadi salah satu pilihan. Ditinjau dari geografis Indonesia, pengembangan pemanfaatan air sebagai penghasil energi listrik sangat potensial karena sumber air yang melimpah dan belum termanfaatkan dengan baik [3]. Energi listrik melalui elektrokimia merupakan salah satu energi listrik alternatif yang dapat dihasilkan dengan memanfaatkan proses reduksi-oksidasi dimana elektroda negatif (anoda) akan mengalami reaksi oksidasi sehingga elektron yang berada pada permukaan anoda akan terlepas dan dibawa oleh ion elektrolit menuju elektroda positif (katoda) [4].

Salah satu penelitian tentang pemanfaatan sumber daya air untuk energi adalah analisis karakteristik elektrik air laut sebagai sumber energi listrik terbarukan telah kami lakukan melalui penelitian dengan menggunakan 3 variabel elektroda yaitu $C-Z n, C u-A l$, dan $C u-Z n$. Hasil yang diperoleh menunjukkan bahwa pasangan $\mathrm{Cu}-\mathrm{Zn}$ mampu menghasilkan daya listrik yang lebih tinggi dibandingkan pasangan elektroda lainnya [5]. Pada penelitian lanjutan juga telah dilakukan upaya desain dan realisasi accumulator air laut dengan elektroda $\mathrm{Cu}-\mathrm{Zn}$ menggunakan 40 sel. Pada penelitian ini dihasilkan tegangan tanpa beban sebesar 32,84 volt dan mampu menyalakan lampu 1,2 watt selama 72 jam [6].

Permasalahan serius pada logam adalah tingginya laju pengkaratan (corotion) yang dialami oleh elektroda setelah terkena udara (oksigen). Pada penelitian sebelumnya bahwa laju pengkaratan bahan logam yang terendam dalam air laut jika tidak terkena udara (oksigen) berjalan lambat yaitu 5,42 x 10${ }^{5} \mathrm{~mm} /$ year [7]. Angka ini cukup kecil namun adanya lapisan tipis akibat korosi pada permukaan elektroda mempengaruhi daya yang dihasilkan berikutnya meskipun telah dilakukan pengisian ulang dengan air laut yang baru. Adanya kandungan $\mathrm{NaCl}$ pada air laut dapat meningkatkan laju korosi baja karbon yang merupakan paduan seng dan aluminium, sehingga semakin besar konsentrasi $\mathrm{NaCl}$ maka laju korosi akan semakin besar [8].

Sel elektrokimia adalah sistem yang digunakan untuk terjadinya perubahan reaksi oksidasi dan reduksi. Didalamnya dihasilkan listrik melalui pelepasan elektron dari satu elektroda (oksidasi) dan penerimaan elektron pada elektroda lainnya (reduksi). Besarnya daya listrik dan hambatan dalam bahan sangat ditentukan oleh mineral elektrolit yang terkandung dalam cairan pengisi sel elektrokimia [9].

Penelitian ini merupakan pengembangan dari penelitian kami sebelumnya yang difokuskan pada potensi sumber daya air untuk melihat peluangnya sebagai sumber energi alternatif terbarui. Bahan sumber daya air yang digunakan yaitu air payau, dan air sungai dengan memanfaatkan sepasang elektroda tembaga $(\mathrm{Cu})$ dan seng $(\mathrm{Zn})$ yang disusun secara seri [10]. Tujuan penelitian ini adalah mengetahui potensi air payau dan air sungai sebagai sumber energi alternatif melalui karakteristik elektrik dan besarnya energi listrik yang dihasilkannya. Air sungai dan air payau dapat diaplikasikan sebagai bahan elektrolit dalam sel volta untuk menghasilkan energi listrik.

\section{METODE PENELITIAN}

Desain penelitian ini menggunakan alat dan bahan antara lain TDS meter, $\mathrm{pH}$ meter, multimeter digital, water elektrolyzer, gelas ukur, air payau, air sungai, akrilik, tembaga $(\mathrm{Cu})$, seng $(\mathrm{Zn})$, kabel dan jepit buaya, Lampu LED 1,2 watt. Bahan akrilik difungsikan sebagai media uji sel volta berbentuk 
kotak persegi yang terintegrasi dengan 20 sel pasangan elektroda. Elektroda yang digunakan berupa tembaga $(\mathrm{Cu})$, dan seng $(\mathrm{Zn})$, dengan ukuran lebar $5 \mathrm{~cm}$ dan tinggi $6 \mathrm{~cm}$, sedangkan media tempat uji karakteristik kelistrikan air Payau, dan air Sungai, berukuran panjang $10 \mathrm{~cm}$, lebar $6 \mathrm{~cm}$ dan tinggi 6 $\mathrm{cm}$.

Penelitian dilakukan dalam tiga tahap, yaitu perancangan perangkat keras, pengujian alat dan pengambilan data. Tahap pertama pembuatan kotak media uji sel volta sebagaimana terlihat pada GAMBAR 1, sedangkan tahap pengujian merupakan tahapan apakah sistem telah memberikan respon ketika kedua elektroda dalam kotak uji diberi masukan sel elektrolit. Respon sistem diketahui dari hasil pengukuran multimeter.

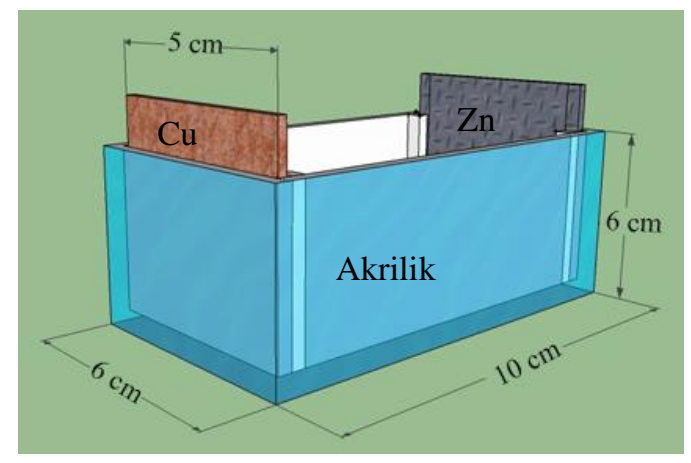

Gambar 1. Kotak media uji sel volta berbahan akrilik

Tahap ketiga merupakan pengambilan data yang dilakukan setelah elektrolit dan elektroda di tempatkan pada sel yang dibuat dan dibiarkan selama 24 jam (GAMBAR 2). Data yang diambil terdiri dari data pengamatan karakteristik kelistrikan (yaitu, tegangan dan arus) air payau dan air sungai saat beban dilepas $\left(\mathrm{V}_{\mathrm{bl}}\right)$, saat menggunakan beban $\left(\mathrm{V}_{\mathrm{b}}\right)$, data pengamatan zat padat terlarut pada air payau dan air sungai, ph air payau dan air sungai, dan perubahan warna air payau dan air sungai setelah menggunakan alat Water Elektrolyzer. Beban yang digunakan adalah LED 1,2 watt, selanjutnya pengukuran dilakukan setiap 2 jam selama 3 hari.

Data yang diperoleh selanjutnya ditabelkan untuk mengetahui hubungan antara karakteristik listrik dengan karakteristik fisika larutan elektrolit. Metode kualitatif diterapkan untuk menganalisis data kuantitatif yang ada.

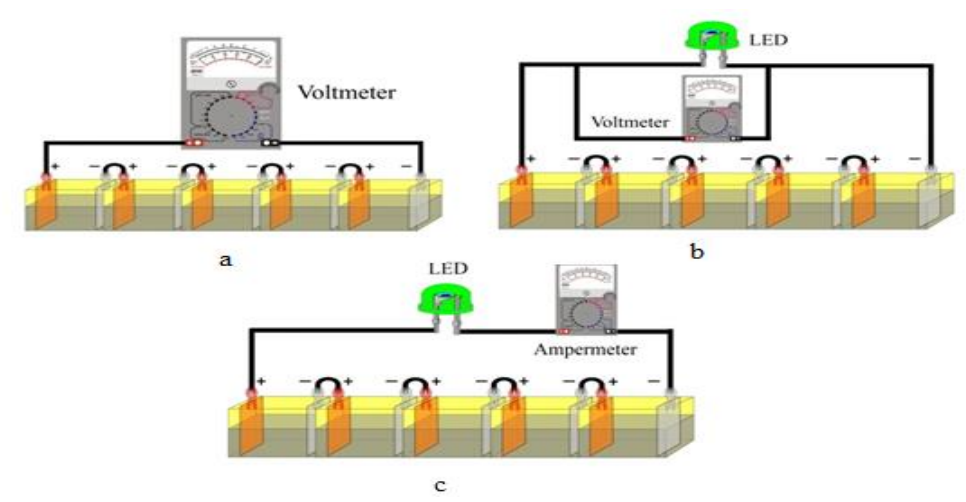

Gambar 2. Langkah pengambilan data penelitian. (a) sistem tanpa pembebanan, (b) pengukuran data tegangan (Volt) dan (c) pengukuran data arus (Ampere) untuk sistem dengan pembebanan 


\section{HASIL PENELITIAN DAN PEMBAHASAN}

Bahan elektrolit yang digunakan adalah air sungai dan air payau. Data tegangan dan arus yang terukur pada sel volta adalah hasil variasi bahan elektrolit, yaitu air sungai dan air payau yang diaplikasikan pada pasangan elektroda $\mathrm{Cu}-\mathrm{Zn}$. Bahan elektroda yang difungsikan sebagai anoda dan katoda berukuran $8 \mathrm{~cm}$ x $5 \mathrm{~cm}$ dan dipasangkan pada tiap-tiap sel. Secara keseluruhan rangkaian pada penelitian ini dapat dilihat pada Gambar 2. Pada rangkaian, pasangan elektroda negatif dan elektroda positif diletakkan pada sisi setiap sel, kemudian antara sel satu dengan yang lain dihubungkan dengan penjepit buaya. Larutan elektrolit air sungai dan air payau dimasukkan pada sel volta yang berisi 20 buah sel (media uji). Sebelum dimasukkan ke media uji, larutan elektrolit diukur nilai derajat keasaman dan kandungan zat terlarut didalamnya, selanjutnya larutan elektrolit sebanyak $250 \mathrm{ml}$ dimasukkan ke media uji. Data nilai arus dan tegangan diperoleh dari hasil pengukuran sel menggunakan multimeter. LED digunakan sebagai beban tambahan untuk mengetahui karakteristik elektrik sel.

\section{Karakterisasi Elektrik Air sungai menggunakan elektroda Cu-Zn}

Gambar 3 dan gambar 4 berikut menunjukkan fluktuasi nilai $\mathrm{pH}$ dan nilai total dissolved suspended (TDS) air sungai selama 3 hari pengukuran. Range rata-rata pengukuran $\mathrm{pH}$ sebesar 6,5 sedangkan nilai TDS sebesar $171,7 \mathrm{mg} / \mathrm{l}$.

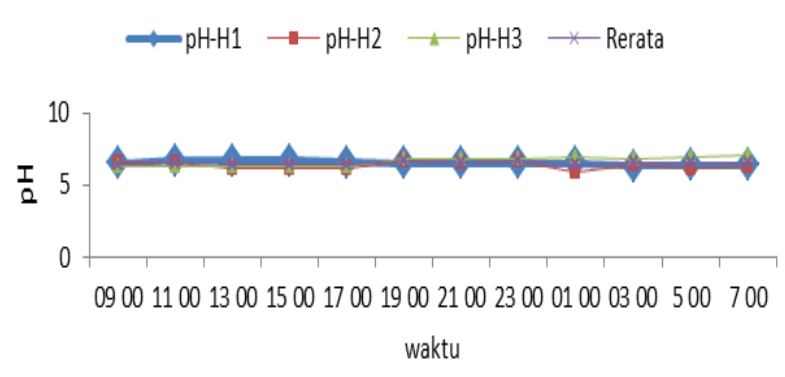

Gambar 3. Grafik fluktuasi pH air sungai

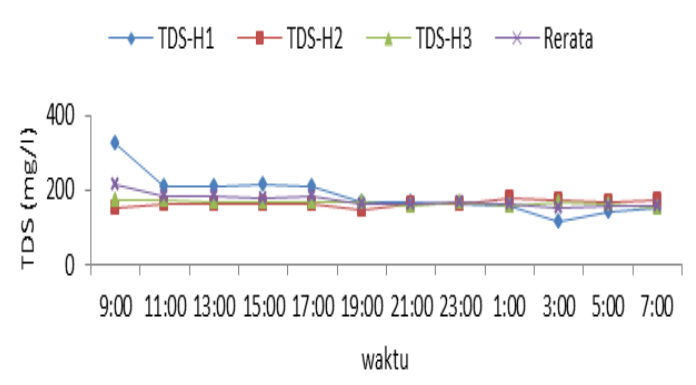

Gambar 4. Grafik fluktuasi TDS air sungai

Pengukuran awal menunjukkan tegangan sel tanpa pembebanan LED menghasilkan nilai rata-rata selama 3 hari pengukuran sebesar 12,3 V (maksimum) dan 11,6 V (minimum) (GAMBAR 5). Pembebanan LED pada rangkaian memberikan nilai kelistrikan sel terukur menurun secara signifikan. GAMBAR 6 memperlihatkan fluktuasi tegangan terukur tersebut, range nilai maksimal tegangan sebesar 7,2 V dan tegangan minimal sebesar 7,1 V.

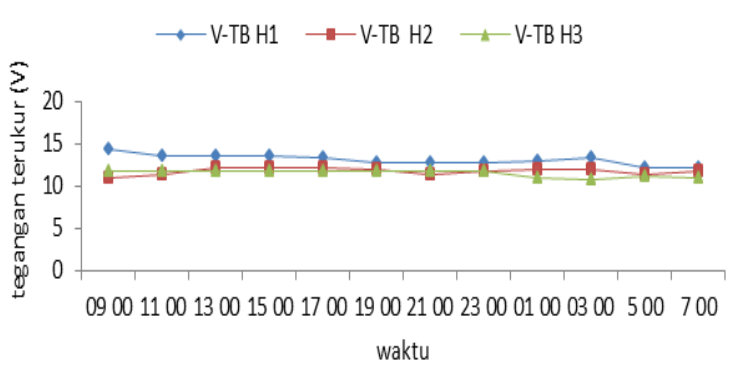

Gambar 5. Fluktuasi tegangan terukur sel berbahan

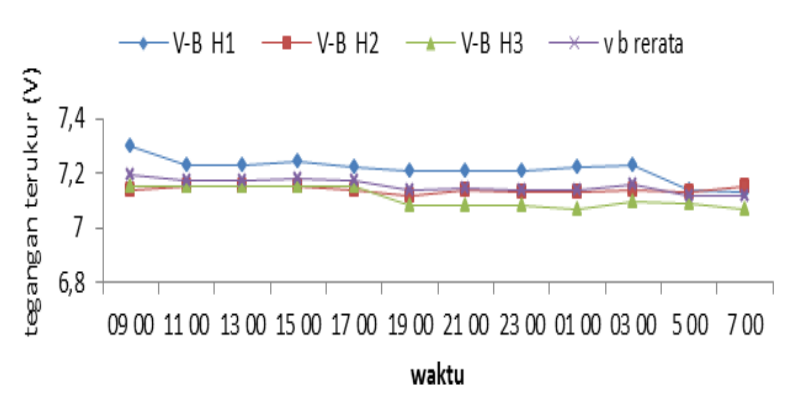

Gambar 6. Fluktuasi tegangan sel berbahan elektrolit air 
Nilai arus terukur (gambar 7) menunjukkan rata-rata pengukuran sebesar 0,32 $\mathrm{mA}$ (maksimal) hingga $0,07 \mathrm{~mA}$ (minimal). Arus listrik terukur cukup besar hanya 2 jam pertama, selanjutnya menurun hingga orde $10^{-2}$. Nilai ini berimbas pada daya listrik rata-rata yang dihasilkan yaitu sebesar $2,3 \mathrm{~mW}$ (maksimal) hingga $0,52 \mathrm{~mW}$ (gambar 8). Nilai daya rata-rata selama tiga hari pengukuran sebesar $0,785 \mathrm{~mW}$.

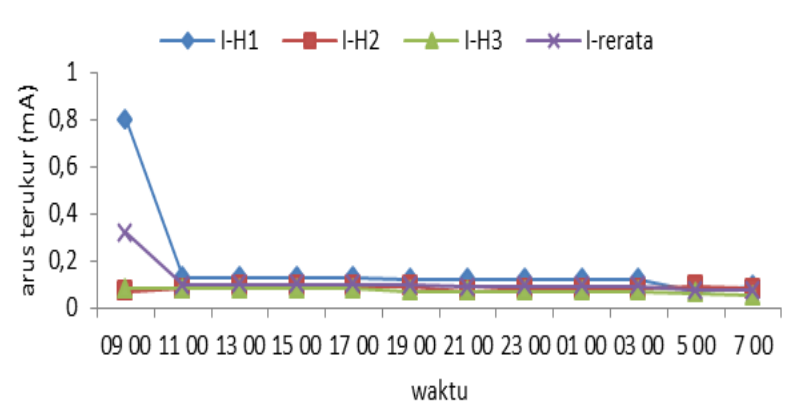

Gambar 7. Fluktuasi arus listrik sel berbahan elektrolit air sungai

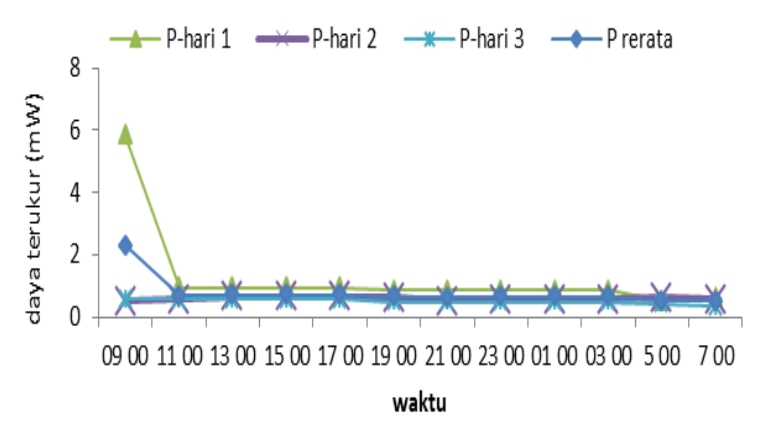

Gambar 8. Fluktuasi daya terukur sel dengan elektrolit air sungai

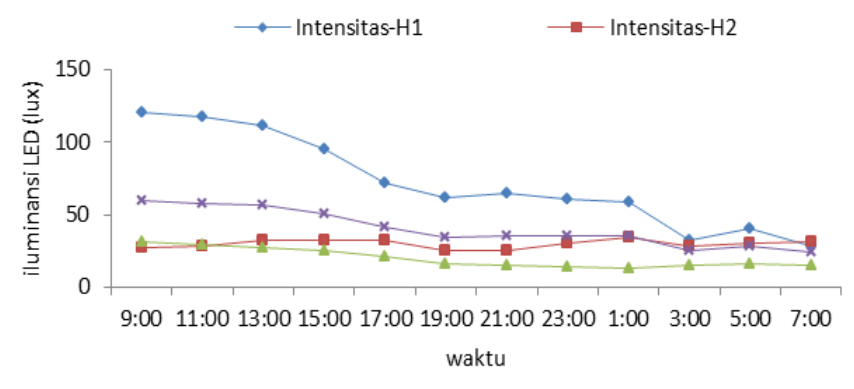

Gambar 9. Fluktuasi intensitas LED menggunakan elektrolit air sungai

Intensitas LED yang terukur menggunakan daya listrik tersebut berkisar 121 lux (hari 1 pukul 09:00) dan terus berkurang hingga 15 lux (hari 3 pukul 07:00). Intensitas rata-rata selama 3 hari pengukuran yaitu 40,4 lux seperti ditunjukkan GAMBAR 9.

\section{Karakterisasi Elektrik Air Payau menggunakan elektroda Cu-Zn}

Air payau mempunyai $\mathrm{pH}$ dan TDS berbeda dari air sungai, sehingga perilaku kelistrikan akan berbeda. Gambar berikut merupakan fluktuasi pH (GAMBAR 10) dan TDS air payau (GAMBAR 11) yang diukur. 


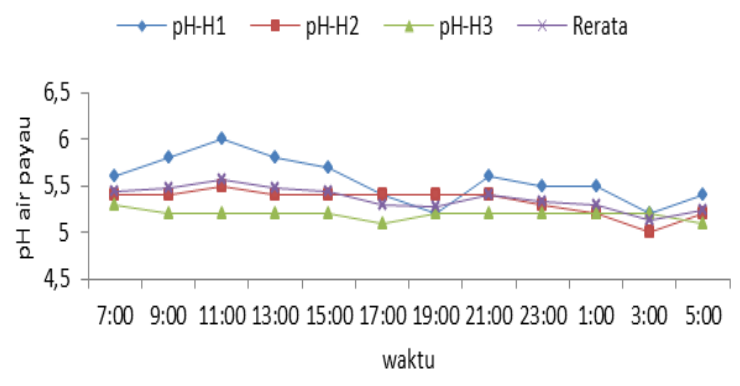

Gambar 10. Grafik fluktuasi pH air payau

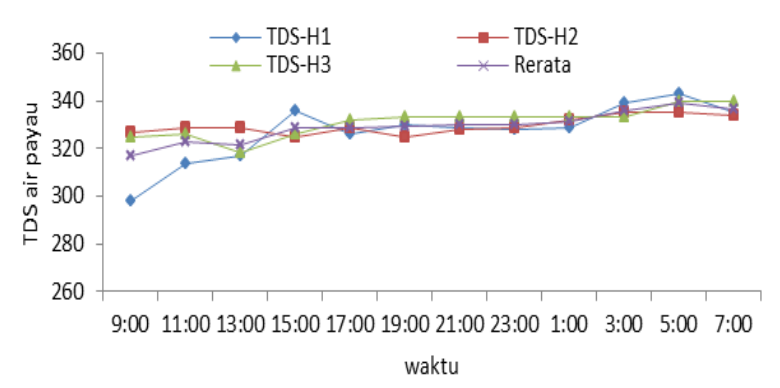

Gambar 11. Grafik fluktuasi TDS air payau

pH rata-rata air payau yang diukur selama 3 hari sebesar 5,4 sedangkan TDS rata-rata sebesar $329,3 \mathrm{mg} / \mathrm{l}$, sedikit lebih besar dari nilai $\mathrm{pH}$ dan TDS air sungai, sehingga patut diduga akan ada kenaikan nilai daya hantar listrik jika sel diisikan air payau.

Gambar 12 menunjukkan nilai tegangan terukur untuk sel dengan elektroda $\mathrm{Cu}-\mathrm{Zn}$ tanpa pembebanan menggunakan elektrolit air payau. Tegangan hari 1 (pukul 07:00) sebesar 14,06 V 9,75 V (pukul 05:00), tegangan hari 2 (pukul 07:00) sebesar 10,18 V - 8,98 V (pukul 05:00), tegangan hari 3 (pukul 07:00) sebesar 8,68 V-8,68 V (pukul 05:00). Nilai rata-rata selama 3 hari pengukuran sebesar 10,97 V (maksimal) hingga 9,13 V (minimal).

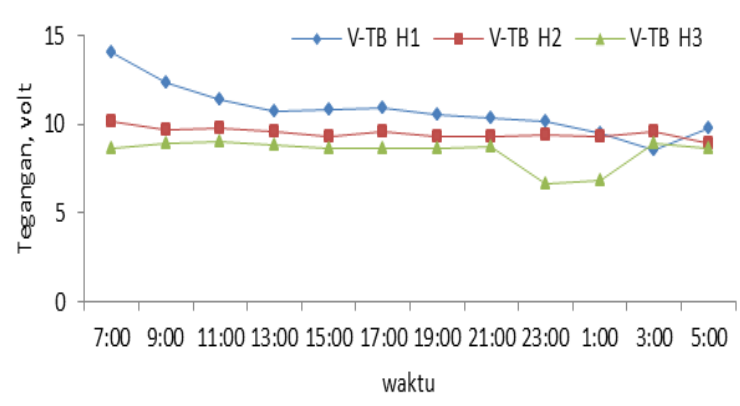

Gambar 12 Grafik fluktuasi tegangan tanpa beban untuk elektrolit air payau

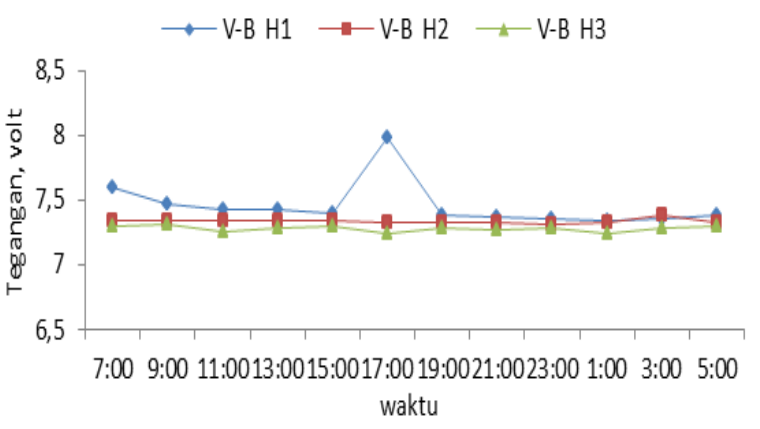

Gambar 13 Grafik fluktuasi tegangan terukur sel yang dibebani LED menggunakan elektrolit air payau

Pada saat elektrolit air payau digunakan pada sel yang diberi beban LED 1,2 watt, karakteristik elektrik ditunjukkan oleh gambar 13. Tegangan terukur selama 3 hari (dari pukul 07:00 sampai pukul 05:00) nilainya cenderung stabil, yaitu rata-rata $7,36 \mathrm{~V}$. Penurunan tegangan terjadi pada 24 jam pertama, setelah itu tegangan terukur nilainya stabil.

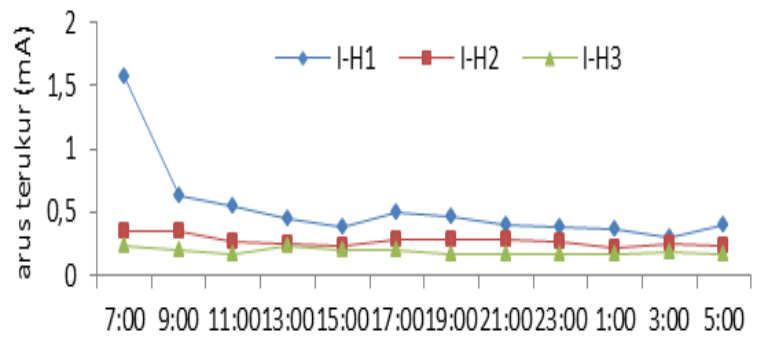

waktu

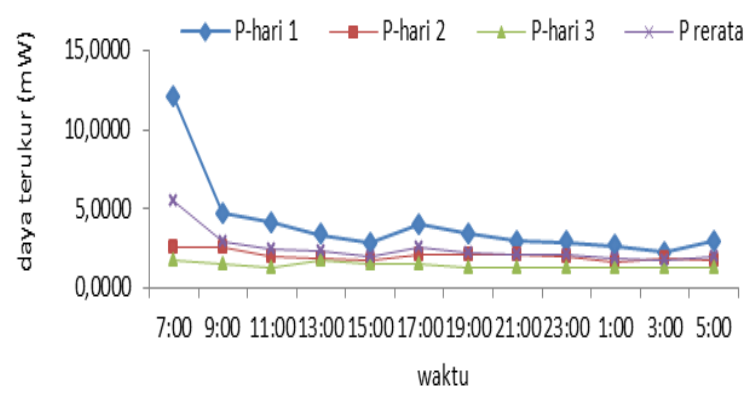

Gambar 15 Fluktuasi daya terukur sel yang dibebani LED 
Arus terukur selama 3 hari (gambar 14) menunjukkan adanya penurunan, hal ini disebabkan ionion yang ada pada larutan elektrolit berkurang akibat reaksi elektrokimia yang terjadi dalam sel volta. Efek reaksi elektrokimia terhadap sel adalah timbulnya korosi atau pembentukan lapisan baru pada keping elektroda yang dipakai. Pada hari 1 (pukul 07:00), arus terukur cukup besar yaitu 1,58 mA kemudian terus berkurang hingga 0,4 mA (pukul 05:00). Penurunan ini berdampak pada daya keluaran sel (gambar 15), yaitu rata-rata sekitar 2,46 watt selama 72 jam atau penurunan dari nilai $12,01 \mathrm{~mW}$ (pukul 07:00 hari 1) hingga 1,24 $\mathrm{mW}$ (pukul 05:00 hari 3).

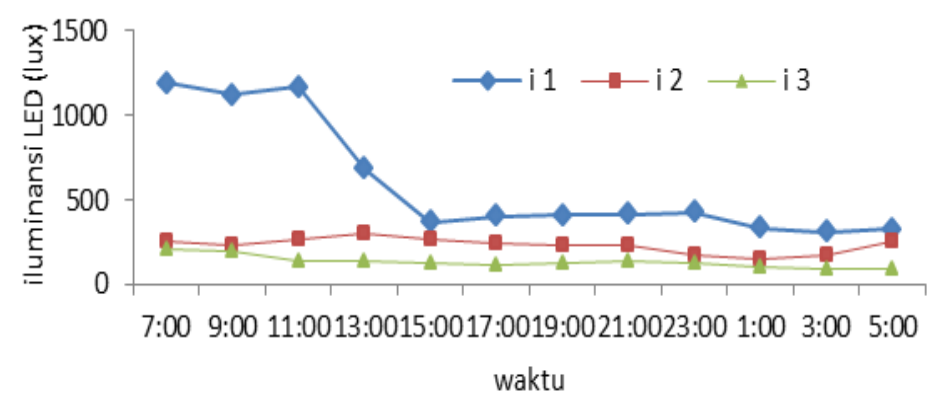

Gambar 16 Fluktuasi intensitas LED untuk sel yang dibebani LED menggunakan elektrolit air payau

Intensitas LED dengan daya rata-rata 2,46 watt selama 72 jam pengukuran bernilai rata-rata 305,8 lux. Intensitas LED selama 24 jam pertama, nilainya sebesar 1192 lux (awal pengukuran), namun setelah pemakaian 18 jam pertama intensitas LED berkurang menjadi 336 lux (gambar 16). Nilai ini terus berkurang seiring waktu pemakaian sel volta, yang mengindikasikan proses elektrokimia dalam air payau mulai menurun. Konsentrasi ion-ion yang berasal dari zat terlarut dalam air payau mulai berkurang.

\section{Perbandingan karakteristik elektrik air sungai dan air payau}

Air sungai sebagai bahan elektrolit sel volta dengan elektroda $\mathrm{Cu}-\mathrm{Zn}$ menunjukkan karakteristik elektrik (tegangan) lebih baik dibanding air payau ketika sel belum diberi beban (gambar 17). Derajat keasaman air sungai $(6,5)$ yang cenderung netral dan nilai TDS air sungai $(171,6 \mathrm{mg} / \mathrm{l})$ yang lebih kecil dari air payau $(\mathrm{pH}=5,4$ dan $\mathrm{TDS}=329,3 \mathrm{mg} / \mathrm{l})$ tidak mempengaruhi proses elektrokimia yang terjadi pada elektroda. Konsentrasi ion hidrogen air sungai cukup kecil sehingga daya hantar larutan elekrolit lemah untuk melakukan pertukaran ion antar elektroda. Pada keadaan ini, yang terukur adalah reaksi elektrokimia pada elektroda $\mathrm{Cu}-\mathrm{Zn}$.

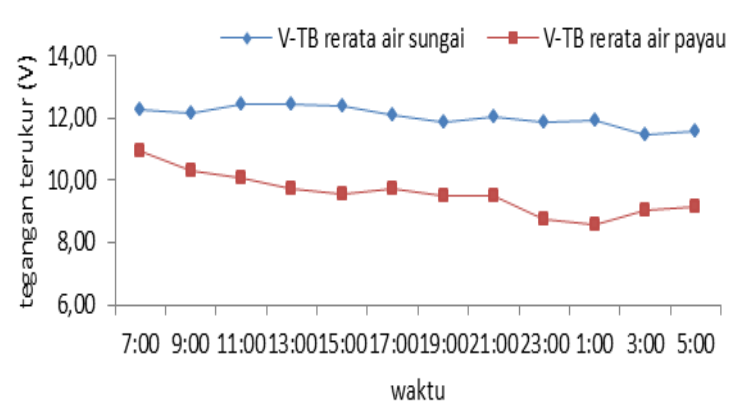

Gambar 17 Perbandingan tegangan tanpa beban, air sungai dan air payau

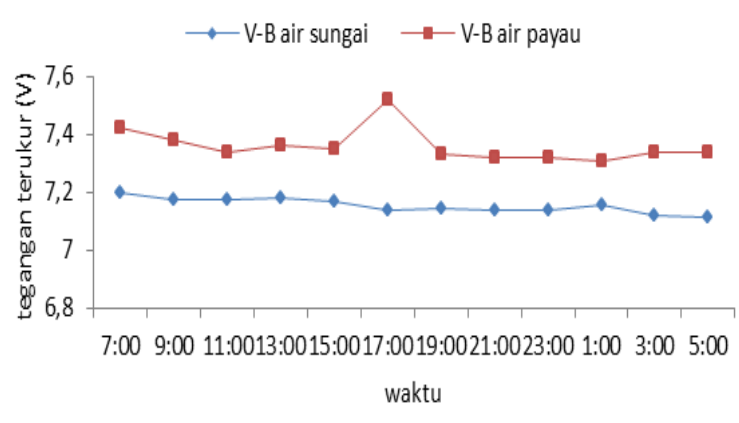

Gambar 18 Perbandingan tegangan dengan beban LED, air sungai dan air payau 
Pada saat sel volta diberi pembebanan LED 1,2 watt, tegangan terukur menunjukkan bahwa elektrolit air payau lebih baik daripada air sungai. Hal ini sesuai dengan teori bahwa derajat keasaman suatu elektrolit dapat meningkatkan pertukaran ion diantara dua elektroda yang berbeda potensialnya. Konsentrasi ion $\mathrm{H}^{+}$air payau yang cukup banyak terlibat dalam proses reduksi oksidasi pada keping elektroda. Transfer elektron oleh ion elektrolit air payau dapat menghasilkan arus listrik dan beda tegangan yang lebih baik dari air sungai (gambar 18).

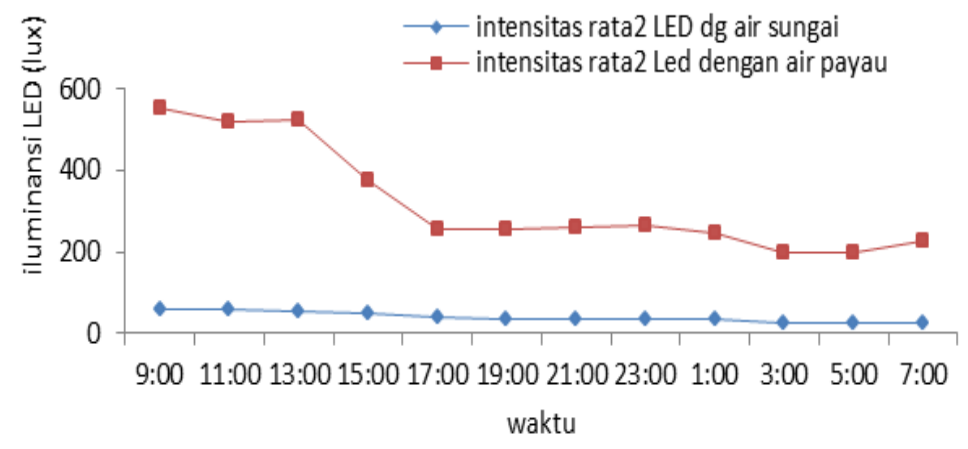

Gambar 19 Perbandingan intensitas LED terukur dalam sel menggunakan elektrolit air payau dan air sungai

Ditinjau dari intensitas LED yang dihasilkan elektrolit air sungai dan air payau (gambar 19), kemampuan air payau lebih baik dalam menghasilkan energi listrik. Elektrolit air payau mampu menghidupkan LED dalam range intensitas rata-rata sebesar 551,3 lux hingga 228,7 lux, dengan arus listrik yang mengalir rata-rata $0,7 \mathrm{~mA}$ hingga $0,3 \mathrm{~mA}$ dan range tegangan rata-rata sebesar $7,41 \mathrm{~V}$ hingga 7,36 V selama 72 jam. Pada elektrolit air sungai, intensitas LED stabil pada range nilai ratarata 59,7 lux hingga 40,4 lux.

Dari karakterisasi elektrik larutan elektrolit air sungai dan air payau, dan dari perbandingan nilai intensitas LED yang terukur, elektrolit air payau dengan pemilihan pasangan elektroda $\mathrm{Cu}-\mathrm{Zn}$ memberikan hasil terbaik. Hal ini disebabkan karena pasangan elektroda $\mathrm{Cu}-\mathrm{Zn}$ merupakan elektroda dengan nilai konduktifitas yang sangat baik (potensial elektrodanya $1,10 \mathrm{~V}$ ), ditambah dengan konsentrasi zat terlarut dalam air payau $(\mathrm{TDS}=329,3 \mathrm{mg} / \mathrm{l}$ ) dan derajat keasaman 5,4 maka proses transfer elektron oleh ion elektrolit menjadikan daya hantar listrik sangat baik. Air payau merupakan air tanah yang berasal dari intrusi air laut, sehingga kandungan salinitas dalam airnya mendekati air laut.

Dalam keadaan terlarut atau cair, garam akan membentuk elektrolit setelah melalui proses elektrolisis dengan reaksi reduksi oksidasi. Terjadinya reaksi reduksi oksidasi disebabkan karena adanya perbedaan potensial kedua elektroda tersebut. Pada penelitian ini pasangan elektroda $\mathrm{Cu}-\mathrm{Zn}$ sangat cocok digunakan sebagai elektroda dengan elektrolit air payau. Hal ini bersesuaian dengan hasil karakterisasi kelistrikan air sungai dan air payau yang menunjukkan air payau adalah elektrolit yang sangat baik untuk elektroda $\mathrm{Cu}-\mathrm{Zn}$.

\section{SIMPULAN}

Air payau mempunyai karakteristik elektrik lebih baik dari air sungai sebagai bahan elektrolit sel volta terlihat dari hasil pengukuran tegangan dan arus pada rangkaian. Tegangan listrik rata-rata yang terukur sebesar 7,41 V hingga 7,36 V sedangkan arus listrik terukur sebesar 0,7 mA hingga $0,3 \mathrm{~mA}$ selama 72 jam. Transfer elektron dalam sel elektroda berlangsung sangat baik sehingga sel volta dengan elektrolit air payau mampu menghidupkan LED 1,2 watt selama 72 jam dengan besar intensitas rata-rata 551,3 lux hingga 228,7 lux. Hasil ini menunjukkan bahwa air payau berpotensi sebagai sumber daya listrik alternatif yang terbaharui, dan untuk meningkatkan energi listrik yang dihasilkan dapat dilakukan dengan menaikkan derajat keasaman air payau. 


\section{UCAPAN TERIMAKASIH}

Terimakasih kepada Fakultas MIPA Universitas Lampung sebagai pemberi dana penelitian, dan tim peneliti yang membantu dalam diskusi hasil.

\section{REFERENSI}

[1] G.Q. Chen and X.F. Wu, "Energy overview for globalized world economy: Source, supply chain and sink". Renewable and Sustainable Energy Reviews, pp 735-749, 2016.

[2] Kementrian Energi dan Sumber Daya Mineral, Materi Paparan Kementrian Energi dan Sumber Daya Mineral Rapat Koordinasi Infrastruktur Ketenagalistrikan. Jakarta. Kementrian Energi dan Sumber Daya Mineral, 2015.

[3] A. Kadir. Energi Sumber Daya, Inovasi, Tenaga Listrik dan Potensi Ekonomi, Edisi Kedua, Universitas Indonesia, Jakarta, 1995

[4] Fariya, Siti dan Sri Rejeki, "SEACELL (Sea Water Electrochemical Cell) Pemanfaatan Air Laut Menjadi Cadangan Sumber Energi Listrik Terbarukan Sebagai Penerangan Pada Sampan”, Jurnal Sains dan Teknologi Instititut Teknologi Sepuluh November, 2015

[5] G.A. Pauzi, Encep Hudaya, Amir Supriyanto, Warsito, "Analisis Uji Karakteristik Elektrik Air Laut sebagai Sumber Energi Listrik Terbarukan", Proseding SN SMIAP 2016, Universitas Lampung, 2016

[6] G.A. Pauzi, Jovizal Aristian, Amir Supriyanto, SW Suciyati, "Desain dan Aplikasi Sistem Elektrolit Air Laut Sebagai Sumber Energi Alternatif Berkelanjutan (Sustainable Energi)", Jurnal Teori dan Aplikasi Fisika 05 (1), Januari Tahun 2017

[7] G.A. Pauzi, Ayu S.A., Dita Rahmayani., Nindi E.M., "Perhitungan Laju Korosi di dalam Air Laut dan Air garam 3\% pada paku dan Besi ASTM 36", Jurnal Ilmiah Penelitian dan Pembelajaran Fisika (Gravity), Jurusan Fisika FKIP Universitas Sultan Ageng Tirtayasa 2015

[8] Palapessy, Victor Rizal, Juliana Anggono, dan Soejono Tjitro. Studi Perbandingan Kinerja Anoda Karbon Paduan Aluminium dengan Paduan Seng dalam Lingkungan Air Laut. Jurnal Teknik Mesin Universitas Kristen Petra. 89-99, 1995.

[9] Anderson, MA., A Cudero and J Palma., "Capasitive deionization (CDI) as an electrochemical means of saving energi and delivering clean water", Electrochimica Acta 55, $3845-3856,2010$

[10] Sudhakar, K, R. Ananthakrishnan, A. Goyal, and H. K. Darji. "A Novel Design Of MultiChambered Biomass Battery". International Journal of Renewable Energi Development (IJRED,.pp. 31-34, 2013.

[11] Tebbutt, T.H.Y. Organic Geochemistry of Natural Waters. MrtinusNijhoff/Dr.W.Junk. Publ, Dordrecht, The Netherlands. 1992. 
Spektra: Jurnal Fisika dan Aplikasinya http://doi.org/10.21009/SPEKTRA
Volume 3 Nomor 1, April 2018
p-ISSN: 2541-3384 e-ISSN: 2541-3392 